\title{
STUDI KELAYAKAN GEDUNG PARKIR KOTA MAKASSAR 1
}

\author{
Hakim Duppa \\ Dosen Teknik Prodi Arsitektur Fakultas Teknik \\ Universitas Pepabri Makassar \\ Jalan Cendrawasih No. 15 b-c Makassar: hduppa@yahoo.co.id
}

\begin{abstract}
The availability of parking spaces in Makassar City at this time is not comparable with the increase in the number of people who bring cars, motorbikes, because of the limited parking space available, one alternative solution is to build a parking building. This study aims to analyze the feasibility of building a parking building and find out the Willingness To Pay (WTP) of the population for alternative parking and parking tariff systems. License Plate surveys are conducted to find out the number of cars parked at this time. The survey results are used to predict parking plot requirements in the next few years and estimate the cost of parking building construction. In this study compared two alternative parking buildings, namely Alternative I which consists of two buildings with four floors each and Alternative II, namely one building with a height of seven floors. Whereas to find out the WTP on the parking tariff system, questionnaires were distributed with the question format based on the Choice Modeling method which is one method of Stated Preference. The results of the Break Even Point (BEP) and Benefit-Cost Ratio ( $B$ / $C$ ratio) analysis of both parking building alternatives indicate that BEP will be achieved after 30 years with $B / C$ ratio $=2.95$ (Alternative I) and 2.50 (Alternative II). The results of the WTP analysis indicate that Alternative I with the daily tariff system is preferred by the public and the departmental factors have an influence on the choice ofparkingalternatives.
\end{abstract}

Keywords: Parking building, Willingness To Pay, Choice Model. 


\begin{abstract}
Abstrak
Ketersediaan lahan parkir di Kota Makassar pada saat ini tidak sebanding dengan bertambahnya jumlah penduduk yang membawa mobil, motor, karena keterbatasan luas lahan parkir yang tersedia, salah satu alternatif pemecahannya adalah dengan membangun gedung parkir. Penelitian ini bertujuan untuk untuk menganalisa kelayakan pembangunan gedung parkir dan mengetahui Willingness To Pay (WTP) penduduk terhadap alternatif parkir dan sistem tarif parkir. Survey License Plate dilakukan untuk mengetahui jumlah mobil yang parkir pada saat ini. Hasil survey dipergunakan untuk memprediksi kebutuhan petak parkir beberapa tahun mendatang dan memperkirakan biaya konstruksi gedung parkir. Dalam penelitian ini dibandingkan dua alternatif gedung parkir yaitu Alternatif I yang terdiri dari dua gedung dengan ketinggian masing-masing empat lantai dan Alternatif II yaitu satu gedung dengan ketinggian tujuh lantai. Sedangkan untuk mengetahui WTP terhadap sistem tarif parkir dilakukan penyebaran kuesioner dengan format pertanyaan berdasarkan metode Choice Modelling yang merupakan salah satu metode dari Stated Preference. Hasil analisa Break Even Point (BEP) dan Benefit-Cost Ratio (B/C ratio) terhadap kedua alternatif gedung parkir mengindikasikan bahwa BEP akan tercapai setelah 30 tahun dengan $\mathrm{B} / \mathrm{C}$ ratio $=2,95$ (Alternatif I) dan 2,50 (Alternatif II). Hasil analisa WTP mengindikasikan bahwa Alternatif I dengan sistem tarif harian lebih diminati oleh masyarat dan faktor jurusan mempunyai pengaruh terhadap pemilihan alternatif parkir.

Kata kunci: Gedung parkir, Willingness To Pay, Choice Model.
\end{abstract}




\section{PENDAHULUAN}

Peningkatan jumlah penduduk
berdampak pada pertambahan
kebutuhan akan petak parkir mobil di
Kota
mempertimbangkan keterbatasan lahan parkir maka alternatif solusi yang diusulkan adalah membangun sebuah gedung parkir. Tujuan penelitian adalah untuk menganalisa kelayakan pembangunan gedung parkir dan mengetahui Willingness To Pay (WTP) mahasiswa terhadap alternatif parkir dan sistem tarif parkir. Analisa kelayakan pembangunan gedung parkir dibatasi hanya dengan menggunakan metode BEP dan B/C Ratio. Sedangkan biaya konstruksi gedung parkir hanya merupakan perkiraan saja.

\section{Aspek perancangan}

makro.

A. Lokasi

Lokasi terletak di Kecamatan

Panakkukang dengan luas wilayah kecamatan 17,05 $\mathrm{Km}^{2}$ dengan batas-batas wilayah meliputi :

Sebelah Utara : Kecamatan Tallo

Sebelah Timur : Kec. Manggala

Sebelah Selatan : Kec. Tamalate

Sebelah Barat : Kec. Rappocini

Adapun pertimbangan dipilinnya

Kecamatan Panakkukang sebagai lokasi, antara lain :

1.Jumlah penduduk 146.968 jiwa dengan kepadatan penduduk sebesar 8.620 jiwa $/ \mathrm{km}^{2}$

2. Kategori padat dalam tingkat kepadatan arus lalu lintas kota

3.Merupakan pusat bisnis, perdagangan dan jasa serta permukiman

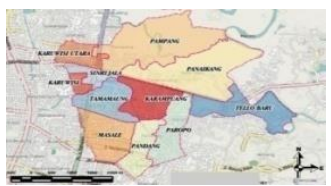

Gambar 2.1 Peta Kecamatan Panakkukang Sumber : Kec. Panakkukang Dalam Angka, 2016

B. Tapak

Tapak yang terpilih terletak di Kelurahan Masale dengan luas wilayah 1,32 $\mathrm{Km}^{2}$, dengan batas-batas wilayah sebagai berikut

Sebelah Utara : Kelurahan

Tamamaung

Sebelah Timur : Kelurahan Pandang

Sebelah Selatan : Wilayah Kec Rappocini Sebelah Barat:Wilayah Kec. Rappocini

Adapun pertimbangan awal dipilihnya Keluran Masale, antara Iain :

1. Jumlah penduduk 11.967 jiwa dengan kepadatan penduduk sebesar 9.066 jiwa $/ \mathrm{km}^{2}$

2. Merupakan area bisnis berupa hotel, restoran, rumah makan, mall, rumah toko, pusat perbelanjaan dan perkantoran

3. Memiliki hingga tiga akses jalan utama dan dilalui angkutan umum serta ada beberapa jalan arteri

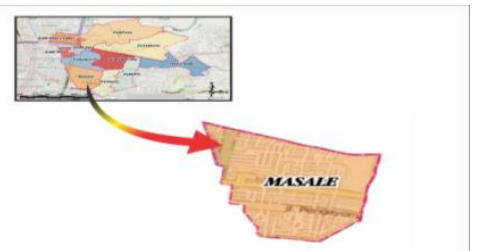

Gambar 2.2 Site dari Kelurahan Masale Sumber : Kec. Panakkukang Dalam Angka, 2016 


\section{Perancangan Tapak}

1. Aksesibilitas

Aksesibilitas adalah ukuran kemudahan dicapai oleh manusia, terhadap suatu objek, berupa pelayanan ataupun lingkungan. Kemudahan akses tersebut diimplementasikan pada bangunan gedung, lingkungan dan fasilitas umum lainnya. Di bidang transportasi, aksesibilitas adalah kemudahan mencapai suatu tujuan, dengan tersedianya berbagai rute alternatif menuju satu tempat.

Pada tapak ini, ada 2 (dua) akses dalam kemudahan pencapaian ke tapak, diantaranya yaitu :

a. Jalan Pengayoman yang merupakan jalan kolektor primer dengan lebar $16 \mathrm{~m}$ sebagai jalan utama dengan dua arah arus lalu lintas. b. Jalan lokal dengan lebar $6 \mathrm{~m}$ yang ada di sekitar tapak.

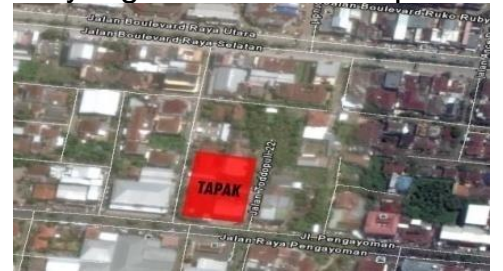

Gambar 2.3 Peta Lokasi Tapak

$$
\text { Sumber : Google Ma }
$$

\section{View}

View dalam arsitektur adalah arah pandang/pandangan yang dapat dilihat dari tapak menuju ke luar tapak. Dalam hal ini cukup berpengaruh di dalam bangunan maupun di luar bangunan. View bangunan secara umum lebih ditunjukkan untuk menempatkan posisi bangunan yang sesuai dengan potensi-potensi positif dan menghindari hal-hal negatif di dalam maupun di luar lingkungannya.
Ada 3 (tiga) view yang dapat diperoleh dari lokasi tapak yang telah ditentukan, yaitu :

a. Dari arah Jalan Pengayoman, tapak berhadapan langsung ke jalan kolektor yang merupakan pusat kegiatan yang akan diwadahi.

b. Dari arah Jalan Boulevard, tapak menghadap ke lingkungan padat permukiman berupa tempat usaha dan bisnis.

c. Dari arah jalan pertigaan dari Boulevard dan Pengayoman, tapak menghadap ke jalan lokal yang merupakan jalan alternatif yang menghubungkan Jalan Pengayoman dan Boulevard.

Dari ketiga view yang telah dijelaskan sebelumnya, maka view yang baik adalah yang mengarah ke Jalan Pengayoman, dengan pertimbangan :

a. Pandangan terbuka, sebab mengarah ke Jalan Raya Pengayoman

b. Aksesibilitas, pencapaian yang mudah untuk menuju ke tapak

c. Entrance, strategis untuk dijadikan sebagai arah keluar-masuk ke tapak

\section{Entrance}

Entrance merupakan suatu ruang yang menyediakan akses untuk masuk atau keluar, berupa pintu atau jalan masuk dari bangunan atau sebagai area penerima. Pada umumnya ada 3 (tiga) jenis penempatan entrance dalam mengolah tapak terkait dalam mengatasi permasalahan yang muncul pada tapak. Diantaranya yakni :

a. Main Entrance, (Jalur Masuk) ditempatkan pada jalur yang lebih 
muda dijangkau oleh pengunjung untuk masuk. Jalur keluar-masuk dari mobil di Gedung Parkir ini terletak di Jalan Pengayoman.

b. Side Entrance, (Jalur Keluar) ditempatkan pada jalur yang cepat dijangkau oleh pengunjung untuk meninggalkan tapak. Pemanfaatan jalan lokal yang ada disekitar tapak bisa dimanfaatkan sebagai Side Entrance dari Gedung Parkir ini.

c. Service Entrance, ditempatkan pada area yang jauh dari kontak langsung alur sirkulasi kendaraan dan juga pengunjung. Penempatan Service Entrance pada bangunan biasanya diposisikan di bagian belakang tapak.

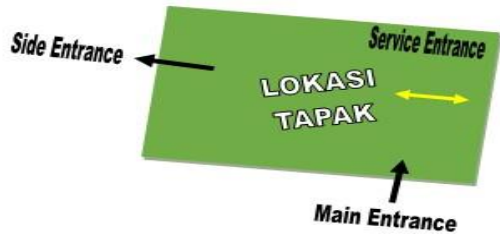

Gambar 2.4 Penempatan Entrance

Sumber : Ilustrasi Penulis

4. Orientasi Bangunan

Orientasi bangunan merupakan salah satu aspek dalam penataan bangunan yang harus dipertimbangkan dengan baik, Orientasi bangunan berpengaruh pada temperatur udara (iklim) sehingga aspek tersebut harus diperhatikan dalam proses perancangan tapak.

Ada 2 (dua) hal yang utama dalam pengaturan orientasi dari bangunan, yaitu :

a. Orientasi terhadap sinar matahari

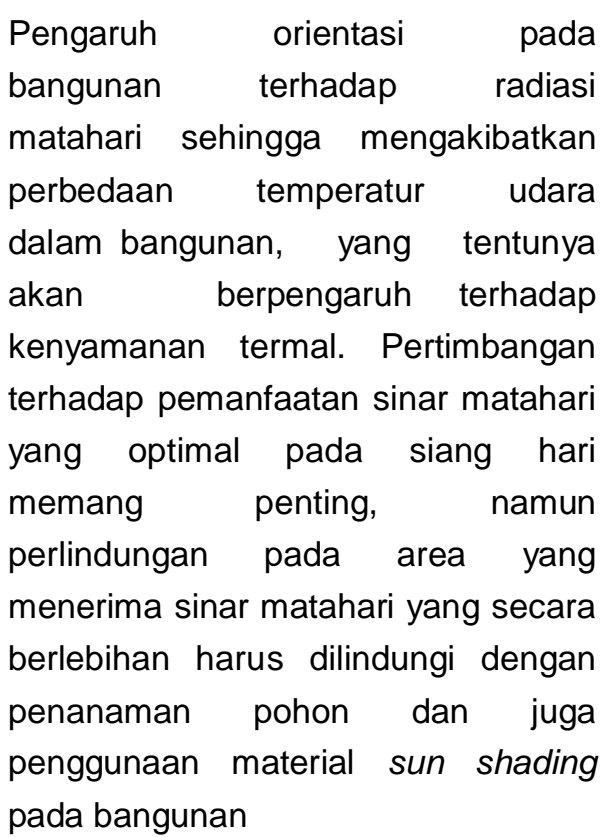

b. Orientasi terhadap arah angin

Angin menjadi faktor penting dalam proses perancangan. Angin dapat membantu mempercepat penguapan pada kondisi kelembaban yang tinggi. Angin juga dapat membantu pendinginan dengan mengalirkan udara dingin sehingga terjadi keseimbangan temperatur yang diinginkan. Ventilasi atau bukaan pada bangunan yang umumnya berfungsi sebagai tempat untuk mengalirkan udara segar. Sehingga harus dirancang dengan konfigurasi tertentu agar terjadi aliran udara. .

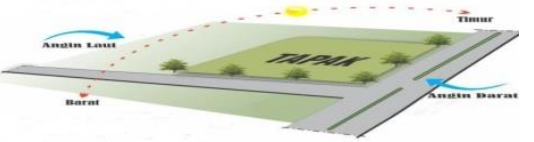

Gambar 2.5 Orientasi Matahari dan Angin Sumber : Ilustrasi Penulis

\section{Pola Tata Massa}

Massa utama berupa bangunan gedung parkir itu sendiri dan didukung dengan unit-unit penunjang lainnya di dalam tapak demi mencapai fungsinya sebagai sarana 
atau bangunan untuk memarkirkan kendaraan.

Meskipun begitu ada tiga hal yang perlu diperhatikan dalam pengaturan massa bangunan pada gedung parkir, yaitu :

1. Kelancaran pada sirkulasi

2. Kemudaham dalam pengawasan

3. Pertimbangan dari tingkat keamanan

Perwujudan pola massa bangunan yang sesuai dengan bentuk massa dan fungsi bangunan sebagai wadah fasilatas perparkiran maka dipilih pola massa linear bersifat monolit, mengelompokkan seluruh kegiatan pada satu massa yang terdiri dari kegiatan pengelolaan, utama, penunjang dan servis. Efektifitas dan efisiensi pemakaian ruang, serta hubungan ruang yang menyeluruh dikelompokkan pada satu massa. Dengan pengaturan bidang-bidang yang tidak monoton ataupun seragam akan menjadi faktor pembentuk ruang yang sesuai dengan fungsinya.
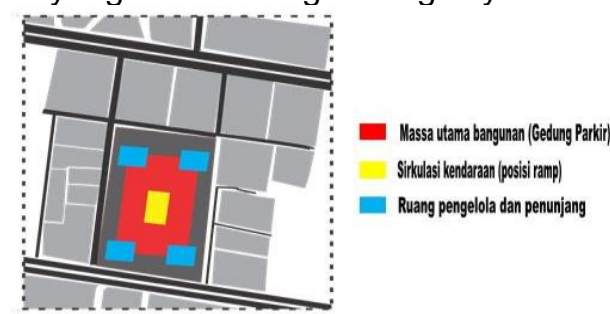

Sirkulasi kendaraan (posisi ramp)

Ruang pengelola dan penunjang

Gambar 2.6 Tata Massa Bangunan

Sumber : Ilustrasi Penulis

\section{E. Pengkondisian Ruang}

1. Sistem Pencahayaan

Pencahayaan merupakan faktor yang mendukung terciptanya kualitas ruang yang baik. Pencahayaan yang cukup dalam kompleks bangunan mutlak diperlukan. Kegiatan di dalam Gedung Parkir menuntut adanya cahaya yang cukup untuk turut serta membantu penerangan baik di dalam ruangan maupun pada lingkungan sekitar.

Ada dua sistem pencahayaan yang biasanya digunakan, yaitu:

a.Pencahayaan alami (natural lighting), yaitu memanfaatkan pantulan cahaya matahari dari langit untuk menerangi bagian dalam ruangan.

b.Pencahayaan buatan (artificial lighting), yaitu menggunakan cahaya lampu yang dinyalakan oleh listrik.

Sistem pencahayaan akan memanfaatkan seoptimal mungkin pencahayaan alami dan dibantu dengan pencahayaan buatan pada waktu malam hari dan juga pada ruangan tertentu.

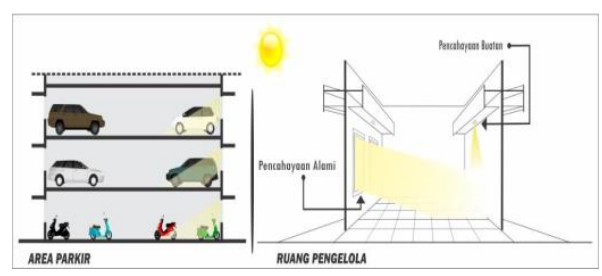

Gambar 2.7 Sistem Pencahayaan

Sumber : Analisa Penulis

2. Sistem Penghawaan

Gedung Parkir merupakan bangunan yang memiliki begitu banyak bagian ruang terbuka. Penghawaan alami dimaksimalkan pada bagian-bagian tertentu yang terbuka. Area yang tidak mendapat penghawaan alami akan menggunakan sistem AC (Air Condition) atau penghawaan buatan lainnya. 


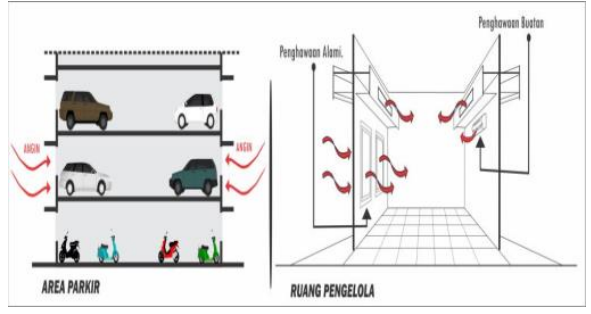

Gambar 2.8 Sistem Penghawaan

Sumber : Analisa Penulis

3. Akustik

Menyadari bahwa bangunan dari Gedung Parkir berposisi di tepi jalan raya sehingga memiliki potensi yang sangat besar dalam tingkat kebisingan yang tinggi, maka perlu mempertimbangkan solusi mengenai permasalahan tersebut.

Akustik bangunan bertujuan untuk berusaha menghambat transmisi suara antar ruangan dari bangunan atau untuk mencegah kebisingan eksternal saat memasuki gedung. Sudut pandang akustik bangunan terdiri dari dinding, lantai dan langitlangit yang memisahkan ruang berbeda satu sama lain atau dari luar. Prasyarat yang diperlukan untuk perlindungan kebisingan yang baik ialah membangun sebuah insulasi suara cukup tinggi pada elemen tersebut. Hal yang sama juga berlaku untuk pintu dan jendela.

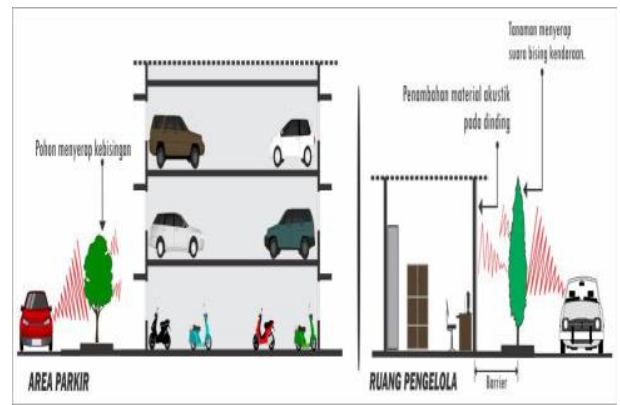

Gambar 2.9 Sistem Akustik

Sumber : Analisa Penulis

\section{Desain Konstruksi Gedung Parkir}

Ketersediaan lahan parkir dan besarnya tarif parkir mempengaruhi jumlah kendaraan parkir di suatu daerah.

Di Makassar, penggunaan on-street parking cenderung kurang teratur sehingga lebih banyak digunakan jenis off-street parking pada komplek usaha dan perbelanjaan. Dengan off-street parking tercapai kepuasan konsumen, kenyamanan, gangguan yang minimum terhadap lalulintas. (Birk, 1993)

Beberapa jenis off-street parking:

- SurfaceCar Parks

Pengaruh utama layout surface car parks adalah ukuran petak parkir yang tergantung pada sudut parkirnya $\left(30^{\circ}, 45^{\circ}, 60^{\circ}, 90^{\circ}\right)$. Tetapi yang paling banyak digunakan adalah sudut $90^{\circ}$ karena terbukti paling efektif dan efisien.

\section{- Multi Storey Car Parks}

Pembangunan gedung parkir Kota Makassar diusulkan menggunakan jenis multi storey car parks, terdiri dari sebaris platform yang didukung dengan kolom dengan jarak yang diijinkan untuk pengaturan layout parkir yang efisien dan jalur untuk sirkulasi kendaraan. Selain itu harus diperhatikan juga bahwa ramp dan floor system harus mempunyai kemiringan dan jari-jari minimum yang diijinkan atau yang memenuhi standar.

Beberapa hal yang perlu diperhatikan dalam desain multi storey car park (O'Flaherty, 1997):

$>$ Jenis dan kemiringan ramp sangat berpengaruh pada tata letak petak parkir.Kemiringan ramp yang 


$\begin{array}{lr}\text { digunakan pada umumnya } & \text { antara } \\ \text { berkisar } & 10 \%- \\ \text { 12\%sedangkan batas } & \\ \text { maksimumnya adalah } & 15 \% \\ \text { (AASHTO, 1992) } & \end{array}$

$>$ Ketinggian antar lantai (floor to floor), berkisar antara $10 \mathrm{ft}$ $(3,05 \mathrm{~m})$ (Multi Storey CarParks, 1990)

$>$ Tinggi bebas (vertical clearance), berkisar antara $7 \mathrm{ft}$ $(2,13 \mathrm{~m}) \quad$ (Multi Storey CarParks, 1990)

$>$ Jarak antar kolom, umumnya diantara dua kolom dapat diisi 3 kendaraan, dengan perhitungan lebar kendaraan sebesar $1,80 \mathrm{~m}$ dan jarak antar kendaraan sebesar $0,525 \mathrm{~m}$, dan ukuran kolom diperkirakan sebesar $0,50 \mathrm{~m}$. Sehingga didapat jarak antar kolom sebesar $8,1 \mathrm{~m} \quad(1,80 \times 3+$ $0,525 \times 4+0,50=8,10 \mathrm{~m})$ (Multi Storey Car Parks,1990)

> Macam bahan konstruksi yang dipakai untuk desain gedung parkir bervariasi, bisa digunakan baja, cast in place concrete, precast concrete dan prestressed concrete.

Sedangkan dari segi penempatan kolomnya dapat dibagi menjadi dua sebagaimana terlihat pada Tabel 1 (Wolfgang, 1982).

\section{A. Besaran Ruang}

Menentukan besaran ruang yang baik yang sesuai dengan dasar pertimbangannya dari aktivitas pemakai ruang, efektifitas dan efisiensi pemakaian ruang, organisasi ruang, dan kesesuaian fungsi di dalamnya. Sedangkan faktor penentu atau yang mempengaruhi adalah aktivitas dan peralatan yang dipakai, satuan ruang, bentuk ruang dan sirkulasi.

\section{Berdasarkan buku yang} berjudul Human Dimension and Interior Space, presentase sirkulasi pada ruang dapat dibedakan menjadi beberapa bagian, yaitu :
$\square 10 \%$ standar aliran gerak minimum
$\square 20 \%$ kebutuhan keleluasaan sirkulasi
$\square 30 \%$ kebutuhan tuntutan kenyamanan
$\square 40 \%$ kebutuhan tuntutan kenyamanan $\square$ $60 \%$ kebutuhan tuntutan spesifik
$\square 70-100 \%$ keterikatan dengan kegiatan

\section{B. Bentuk Bangunan}

Bangunan gedung parkir ini akan menjadi bangunan yang menonjolkan bentuk dari sistem strukturnya yang tidak hanya memperhatikan kekuatan bangunan tapi juga keindahan bangunan. Mengekspos struktur dan konstruksi akan mempunyai nilai keindahan tersendiri dari segi arsitektur. Bentuk bangunan yang monumental serta selaras dengan lingkungan, mampu memberikan kesan mendalam dan menjadi landmark dari kawasan.Pendekatan hitech architecture merupakan suatu konsep perancangan yang menghasilkan suatu bangunan pintar (smart building) serta dapat beroperasi secara efektif dan efisien, untuk memenuhi tuntutan zaman modern saat ini. Dalam pendekatan hitech architecture, rancangan harus dapat menunjukkan secara jelas fungsi dan identitas dari bangunan melalui pengolahan ruang dan pengolahan wajah bangunan dengan memanfaatkan unsurunsur teknologi modern sehingga dapat 
tercipta sebuah bangunan yang mempermudah aktifitas pengguna bangunan itu sendiri.Konsep dasar dari hitech architecture yang kemudian diterapkan pada bentuk dasar dair Gedung Parkir ini, antara lain:

\section{$\square$ Inside-out}

Tampilan dalam terlihat dari luar, bagian struktur dan servis yang terekspos. Seperti penonjolan sistem struktur, menampilkan sistem utilitas atau area servis dari luar.

\section{Celebration of process}

Keberhasilan suatu proses, penggunaan material pabrikasi terkini seperti material baja dan komposit yang proses pemasangannya cepat sesuai perencanaan.

\section{Transparancy, Layering and}

\section{Movement}

Transparan, berlapis dan bergerak, penggunaan kaca yang transparan, pelapisan berupa ducting, dan aksentuasi dari escalator/lift yang bergerak.

\section{Flat Bright Colouring}

Pewarnaan yang menyala dan merata, pemberian kesan warna yang bersifat fungsional dan cenderung penggunaan warna-warna terang.

\section{Struktur Bangunan}

Pemilihan dari sistem struktur pada bangunan tinggi ditentukan oleh berbagai macam pertimbangan, seperti fungsi, tingkat kebutuhan, teknologi, efisiensi, serta hal-hal nonteknis seperti ekonomi, peraturan kota, sosial budaya, estetika, simbol, dan lain sebagainya. Pemilihan sistem struktur terdiri dari :

1. Sub Structure (Struktur Bawah)

- Menggunakan pondasi rakit (raft foundation)yang lebih ekonomis karena dapat menghemat biaya penggalian dan penulangan beton

- Keuntungan khusus untuk ruang bawah-tanah yang berada pada atau di bawah muka air tanah yang merupakan peyekat air

- Dapat mengurangi perbedaan penurunan permukaan tanah karena dapat menahan beban secara menyebar

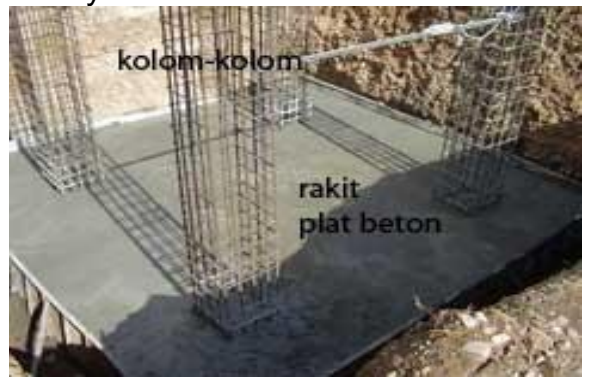

Gambar 3.1 Pondasi Rakit Sebagai Struktur Bawah

Sumber : www.google.com

\section{Super Structure (Struktur Tengah)}

Merupakan struktur yang membentuk suatu rangka ruang. Struktur tengah menggunakan sistem struktur komposit dan baja WF (Wide Flange) sebagai struktur utama, dengan pertimbangan :

- Sistem konstruksi baja memiliki berbagai jenis tampilan estetika dan terlihat modern

- Sistem konstruksi baja memiliki dimensi lebih kecil dan berkesan ringan dibandingkan konstruksi beton

- Pengerjaan sistem konstruksi baja dapat dikerjakan dengan relatif lebih cepat 


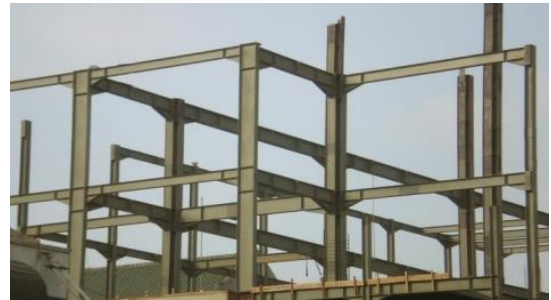

Gambar 3.2 Rangka Baja WF Sebagai Struktur Tengah

Sumber : www.google.com

\section{Upper Structure (Struktur Atas)}

Struktur atap Gedung Parkir harus menggunakan sistem advance yakni penggunaan bentangan lebar sehingga jenis atap yang digunakan ialah jenis Folded Plate dengan pertimbangan :

a.Sangat baik dalam
pengggunaan

bangunan bentangan lebar

b.Efisien dalam menyalurkan beban yang bertumpuh pada tekukan yang ada

c. Pengerjaan yang mudah dan cepat dari segi bahan material berupa plat lipat dan bentuk yang sederhana dibandingkan jenis atap bentangan lebar lainnya.

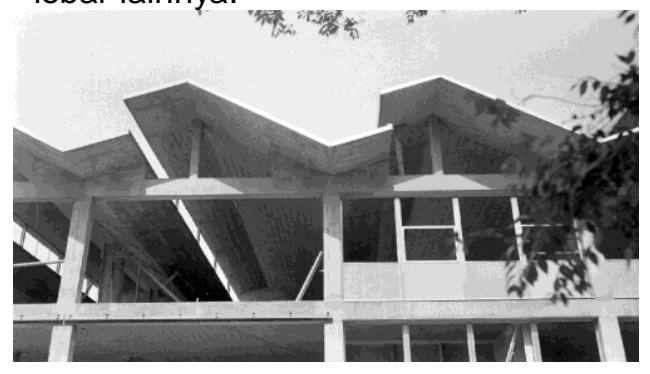

Gambar 3.3 Atap Folded Plate Sebagai

Struktur Atas

Sumber : www.google.com

\section{Analisa Biaya}

Untuk mengetahui kelayakan pembangunan gedung parkir dilakukan dua macam analisa yaitu: a. Break Even Point (BEP) untuk mengetahui seberapa lama waktu yang diperlukan untuk mencapai titik impas dimana besarnya biaya yang dikeluarkan sama dengan besarnya penerimaan yan diperoleh.

b. Benefit/Cost Ratio (B/C Ratio) untuk membandingkan antara keuntungan dengan kerugian akibat pembangunan gedung parkir.

\section{Willingness To Pay (WTP)}

Menurut Tamin (1999) WTP adalah kesediaan pengguna untuk mengeluarkan imbalan atas jasa yang diperolehnya. Pendekatan yang digunakan dalam analisis WTP didasarkan pada persepsi pengguna terhadap tarif dari jasa tersebut.

Untuk mengetahui WTP mahasiwa terhadap alternatif parkir dan sistem tarifnya dilakukan survei dengan menyebarkan kuisioner dengan format pertanyaan berdasarkan metode stated preference. Gambar 1 memperlihatkan beberapa metode dari stated preference.

Contingent Valuation (CV) Method

Berasal dari kata Contingent, teknik ini memperoleh perkiraan nilai dari kesatuan (contingent) beberapa alternatif skenario yang disurvei untuk beberapa responden. Teknik ini lebih banyak memperhatikan faktor lingkungan.

- Open Ended CV Method, Metode ini jarang digunakan karena lebih banyak memperhatikan faktor lingkungan (survei untuk mengetahui WTP tentang usahamengurangi polusi udara). Pada umumnya para responden yang kurang terbiasa dengan hal ini akan merasa bingung sehingga kurang dapat menangkap tujuan dari 
survei yang dilakukan sehingga hasilnya pun akan menjadi kurang akurat (WTP responden dari hasil survei terkadang tidak maksimum).

- Referendum CV Method, Teknik ini meliputi pertanyaan yang ditujukan kepada responden dan responden diharuskan menetapkan satu pilihan diantara dua alternatif.

Model pertanyaan yang sering digunakan untuk metode ini adalah model binary

dimana responden hanya diberi pilihan jawaban "ya" atau "tidak". Ada beberapa

kelemahan dalam memperkirakan nilai WTP dengan menggunakan metode ini adalah:

- Hanya ada satu atribut kualitas pada skenario yang dipakai dalam sampel survei untuk menentukan penilaian responden.

- Rancangan alternatif yang ditawarkan pada umumnya hanya berbentuk perkiraan/hipotesis sehingga responden tidak dapat memberikan jawaban/respon Yang akurat.

- Model ini dapat menyebabkan responden bertindak "strategis" terutama untuk hal-hal yang menyangkut kepentingan umum, mereka terkadang beranggapan bahwa akan ada orang lain yang peduli akan hal tersebut sehingga responden tersebut merasa bahwa dirinya tidak perlu ikut berperan serta dalam mengeluarkan dana.

\section{Conjoint Analysis}

1. Conjoint Rating, dalam metode ini kuisioner disebarkan pada responden untuk memberikan penilaian pada alternatif yang ditawarkan dengan menggunakan skalarating (misalnya memilih satu skala diantara 1 sampai 10). Hampir sama dengan Choice Modelling (CM), metode ini menggunakan atribut yang bervariasi dan telah dipertimbangkan terlebih dahulu. Perbedaannya dengan CM adalah responden tidak perlu membuat perbandingan diantara beberapa alternatif untuk memilih alternatif yang disukai. Pada metode ini, responden memeriksa alternatif yang ditawarkan dan memberikan skala penilaian untuk alternatif tersebut.

2. Conjoint Ranking, perbedaan metode ini dengan Conjoint Rating adalah responden diberi 3 atau lebih alternatif dalam satu pertanyaan dan diharapkan membuat rangking atau urutan dari alternatif-alternatif tersebut (dari yang disukai hingga yang tidak disukai atau sebaliknya). Metode ini tidak lagi digunakan secara luas karena adanya kesulitan dalam pengolahan data yang didapat.

3. Paired Comparison, melalui metode ini responden diharapkan untuk memilih diantara dua alternatif dimana satu alternatif menunjukkan keadaan yang ada saat itu dan alternatif yang lain menunjukkan adanya suatu perubahan. Responden diharapkan memberikan penilaian dalam bentuk skala seperti halnya Conjoint Rating. Metode ini lebih sering digunakan dari ketiga jenis Conjoint Analysis yang ada.

\section{Choice Modelling (CM)}

Dalam metode ini terdapat banyak data sehingga responden dapat memilih diantara lebih dari dua alternatif dimana 
setiap alternatif digambarkan dengan beberapa atribut. Pada umumnya kuisioner yang dibuat dengan menggunakan metode ini mempunyai 5 sampai 8 pilihan dan untuk satu set pilihan terdapat 3 sampai 5 alternatif. Alternatif-alternatif dan atribut yang dipakai dalam metode tersebut bervariasi.

Ada dua hal yang perlu diperhatikan dalam penerapan $\mathrm{CM}$ :

a. Kuesiner harus disampaikan secara langsung (face to face) sehingga cara itu dapat meningkatkan biaya survei.

b. dengan adanya tambahan data yang kompleks berarti survei $\mathrm{CM}$ cenderung memberi respon dengan tingkat yang lebih rendah daripada survei CV.

Kelebihan metode $\mathrm{CM}$ :

1. memberikan beberapa alternatif pilihan untuk dipertimbangkan (kelebihan dan kekurangannya) oleh responden.

2. Masing-masing atribut dijabarkan secara jelas dan alternatifalternatif yang ditawarkan disesuaikan dengan atribut yang ada.

3. Harga-harga yang ditawarkan pada masing-masing alternatif telah diperhitungkan sebelumnya.

4. Dapat memperkirakan tingkat permintaan konsumen.

5. Mengurangi kemungkinan dari responden untuk bertindak "strategis".

Adapun langkah-langkah dalam penggunaan metode $\mathrm{CM}$ dalam pembuatan kuesioner:

a. Identifikasi masalah.
Pemilihan atribut sebagai faktor pembanding.

b. Perancangan dan pengujian alternatif.

c. Perancangan kuesioner dan penentuan cara penyampaiannya.

d. Survei logistik yang meliputi pengujian kuisioner, penentuan spesifikasi sampel dan manajemen seluruh proses survei.

f. Penyebaran kuisioner.

Untuk memperkirakan nilai WTP suatu barang atau jasa, telah diyakini bahwa metode atau teknik yang paling baik dan paling sering digunakan dalam perekonomian adalah Choice Modelling. Sehingga dalam penelitian ini untuk mengetahui WTP mahasiswa tentang sistem tarif parkir digunakan metode. (http://www.ipart.nsw.gov.au/pdf/CIE.pdf)

\section{METODOLOGI PENELITIAN}

Pengumpulan data dilakukan berupa survey license plate dan penyebaran kuesioner yang berisi beberapa pertanyaan mengenai identitas responden sehubungan dengan fasilitas parkir mobil dan sistem pembayarannya.

Dalam penelitian ini dibandingkan dua alternatif gedung parkir yaitu:

- Alternatif I yang terdiri dari dua gedung dengan ketinggian masingmasing empat lantai, yang dibangun secara bertahap gedung pertama beroperasi tahun pertama dan gedung kedua mulai beroperasi tahun ke empat.

- Alternatif II yaitu satu gedung dengan ketinggian tujuh lantai, yang dibangun secara bertahap lantai 1-4 beroperasi pada tahun pertama dan lantai 5-7 mulai beroperas I pada tahun kedua. Adapun alternatif 


\begin{tabular}{|c|c|}
\hline fasilitas & parkir \\
\hline diperbandingkar & seperti \\
\hline
\end{tabular}

\section{ANALISA DATA}

\section{Akumulasi Parkir}

Akumulasi jumlah mobil yang memasuki lahan parkir hasil survey license plate. Jumlah mobil yang masuk lahan parkir mencapai jumlah tertinggi $\overparen{E} 460$ mobil (jam 07.00-08.00) dan total jumlah mobil yang masuk lahan parkir selama 12 jam adalah 1.389 mobil dengan jumlah kebutuhan petak parkir tertinggi dalam satu jam adalah 770 mobil (jam 11:0012:00). Data tersebut digunakan untuk memprediksikan jumlah kebutuhan petak parkir dalam beberapa tahun berikutnya untuk merencanakan kapasitas gedung parkir.

\section{Desain Gedung Parkir}

Beberapa asumsi yang dipergunakan dalam mendesain gedung parkir antara lain:

1. Jenis pondasi yang akan digunakan adalah tiang pancang.

2. Pintu masuk dan keluar dipakai lebar antara 6-8m

3. Kemiringan petak parkir sebesar $90^{\circ}$ karena terbukti paling efisien.

4. Ketinggian antar lantai dipakai $10 f$ $\mathrm{t}(3.05 \mathrm{~m})$ dengan sistem $1 / 2$ lantai

5. Tinggi bebas (vertical clearence) sekitar $7 \mathrm{ft}(2.13 \mathrm{~m})$

6. Jarak antar kolom sebesar $8,1 \mathrm{~m}$.

7. Ramp (jalur perpindahan antar lantai), dipakai sistem setengah lantai dengan arus perputaran kendaraan yang terpisah (Gambar 4).

8. Kemiringan Ramp digunakan kemiringan sebesar $14.252 \%$
9. Kemudahan manuver (perputaran kendaraan) lebar aisle $\mathbb{E} 4.7 \mathrm{~m}$.

Konstruksi yang dipakai adalah beton bertulang (K300) dengan ukuran balok untuk alternatif gedung parkir I sebesar $40 \mathrm{~cm} \times 50 \mathrm{~cm}$ dan kolom yang digunakan berdiameter $50 \mathrm{~cm}$.

Sedangkan untuk alternatif gedung parkir II digunakan balok dengan ukuran $50 \mathrm{~cm} \mathrm{x}$

$60 \mathrm{~cm}$ dan kolomnya berdiameter $60 \mathrm{~cm}$.

Tebal plat untuk kedua alternatif adalah sebesar $15 \mathrm{~cm}$ dan untuk penempatan kolomnya dipakai model shortspan (Chick,1996). Sedangkan untuk bahan penutup atapnya digunakan aluminium gelombang.

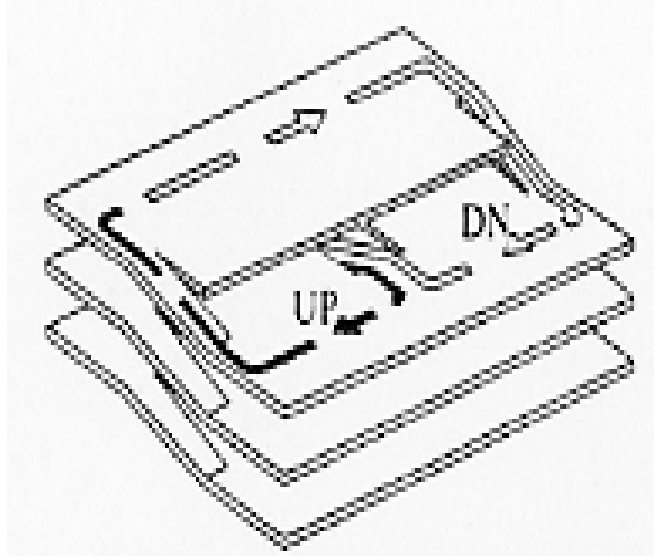

\section{Gambar 4 Sistem Setengah Lantai dengan Arus \\ Perputaran Kendaraan yang Terpisah}

\section{Biaya Konstruksi}

Tabel 3 memperlihatkan perbandingan perkiraan biaya dan spesifikasi antara kedua alternatif gedung parkir berdasarkan asumsi pada bagian sebelumnya.

Berdasarkan perkiraan biaya konstruksi tersebut selanjutnya dilakukan analisa biaya (BEP dan B/C Ratio) yang bertujuan untuk membuat dua alternatif 
fasilitas parkir beserta sistem pembayarannya. Adapun asumsi yang dilakukan dalam pelaksanaan analisa BEP dan B/C Ratio, antara lain:

1. suku bunga yang digunakan dianggap tetap untuk tiap tahunnya yaitu sebesar $13 \%$

untuk peminjaman uang dari bank dan sebesar $6 \%$ untuk bunga tabungan.

2. segala macam pajak yang berlaku tidak diperhitungkan.

3. sebanyak $50 \%$ konsumen memilih alternatif gedung parkir I dengan sistem pembayaran harian dan sisanya memilih sistem pembayaran bulanan.

4. biaya pengoperasian meliputi gaji satpam, beban listrik dan biaya perawatan gedung parkir

Analisa BEP dan B/C Ratio

Perincian perkiraan biaya pengoperasian (Tabel4) dan perincian biaya konstruksi (Tabel 5 dan Tabel 6), serta asumsi penetapan tarif parkir (Tabel 7) dipergunakan dalam analisa BEP dan B/C Ratio untuk mengetahui kelayakan pembangunan gedung parkir Alternatif I dan Alternatif II.

\section{Analisa Chi-Square}

Langkah-langkah analisa Chi-Square adalah sebagai berikut:

1. melakukan coding data kuesioner sehingga sesuai dengan format input program SPSS for Windows untuk uji Chi-Square (Norusis, 1999)

2. asumsi yang dipergunakan dalam analisa Chi-Square adalah:

- $\mathrm{Ho}=$ tidak ada kontingensi

- $\alpha=5 \%$ P-value $<0.05 Æ$ tolak Ho ( ada kontingensi ) P-value $>0.05$ Æ terima Ho ( tidak ada kontingensi )

\section{KESIMPULAN}

1. Bangunan gedung parkir ini akan menjadi bangunan yang menonjolkan bentuk dari sistem strukturnya yang tidak hanya memperhatikan kekuatan bangunan tapi juga keindahan bangunan.. Bentuk bangunan yang monumental serta selaras dengan lingkungan, mampu memberikan kesan mendalam dan menjadi landmark dari kawasan.

2. Pendekatan hi-tech architecture merupakan suatu konsep perancangan yang menghasilkan suatu bangunan pintar (smart building) serta dapat beroperasi secara efektif dan efisien, untuk memenuhi tuntutan zaman modern saat ini.

\section{DAFTAR PUSTAKA}

1. Badan Pusat Statistik Kota Makassar, 2016. Kecamatan

Panakkukang

Dalam Angka 2016, Makassar.

2. De Chiara, Joseph; Julius Panero; Martin Zelnik. 1992. Time-Saver Standard For Interior Design And Space Planning. New York: The Mc-Graw- Hill Companies, Inc.

3. Keputusan Direktur Jenderal PerhubunganDaratNo.272/HK.105/DR JD/96 tentang Pedoman Teknis Penyelenggaraan Fasilitas Parkir.

4. www.google.com/earth/.

5. www.google.com/images/. 